\title{
Perancangan Alat Pemisah Kuning Telur (AMIKUR) dengan Metode Rekayasa Nilai (Studi Kasus di UKM Pempek Dodo)
}

\author{
Felicia $^{1}$, Heri Setiawan ${ }^{2}$ \\ 1,2) Fakultas Sains dan Teknologi, Program Studi Teknik Industri, Universitas Katolik Musi Charitas \\ Jl. Bangau No. 60 Palembang \\ Email: Felicia06042015@gmail.com, herisetiawan1971@gmail.com
}

\begin{abstract}
ABSTRAK
Industri pempek Dodo adalah Industri yang membuat pempek. Industri ini memproduksi pempek telur paling banyak yaitu dengan bahan baku ikan sebanyak 4-5 kg, dengan pemakaian telur sebanyak 60-85 butir. Pempek telur membutuhkan kuning telur yang lebih banyak, sehingga perlu dilakukan pemisahan kuning telur yang memerlukan waktu 25-40 menit. Maka dari itu peneliti merancang "AMIKUR" singkatan dari alat pemisah kuning telur dengan metode rekayasa nilai. AMIKUR berbentuk seperti rel kereta api dan memiliki ukuran dimensi panjang jalur utama 25 $\mathrm{cm}$, panjang jalur tambahan $18 \mathrm{~cm}$, lebar jalur telur $8 \mathrm{~cm}$, lebar alat $7,5 \mathrm{~cm}$, lebar lubang $0,5 \mathrm{~cm}$, tinggi penjepit belakang $13,5 \mathrm{~cm}$, tinggi penjepit depan $9 \mathrm{~cm}$, dan panjang penjepit bawah $25 \mathrm{~cm}$. Alat ini memiliki berat kurang lebih 400 gram. Rata-rata waktu pemisahan kuning telur dengan menggunakan AMIKUR yaitu 4,6 detik/butir, sehingga untuk memisahkan 60-85 butir telur membutuhkan waktu 5-7 menit. Biaya yang dikeluarkan untuk merancang alat ini adalah Rp 138.000,- dan Break Even Point yang didapat sebesar Rp 16.362.516,99 atau sebanyak 5454 pempek serta Payback Period selama 14,47 jam.
\end{abstract}

Kata kunci: Perancangan Alat, Kuning Telur, Rekayasa Nilai, AMIKUR, Waktu Pemisahan, Pempek Telur

\begin{abstract}
Pempek Dodo industry is an industry that makes pempek. This industry produces the most pempek eggs, namely with raw materials of fish as much as 4-5 kg, with the use of 60-85 eggs. Pempek eggs need more egg yolk, so it is necessary to separate the egg yolk which takes 25-40 minutes. Therefore researchers designed "AMIKUR" stands for egg yolk separator with value engineering method. AMIKUR is shaped like a railroad track and has dimensions of the main path length of $25 \mathrm{~cm}$, an additional track length of $18 \mathrm{~cm}$, the width of the egg track is $8 \mathrm{~cm}$, the width of the tool is $7.5 \mathrm{~cm}$, the hole width is $0.5 \mathrm{~cm}$, the rear clamp height is $13.5 \mathrm{~cm}$ the front clamp height is $9 \mathrm{~cm}$, and the clamping length is below $25 \mathrm{~cm}$. This tool weighs approximately 400 grams. The average time of separation of egg yolks by using AMIKUR is 4.6 seconds / grain, so to separate 60-85 eggs it takes 5-7 minutes. The cost for designing this tool is Rp. 138,000, and the Break Even Point is Rp. 16,362,516.99 or 5454 pempek and the Payback Period for 14.47 hours.
\end{abstract}

Keywords: Tool Design, Egg Yolk, Value Engineering, Musculoskeletal, AMUKUR, Time of Separation, Pempek Telur

\section{PENDAHULUAN}

Salah satu industri rumah tangga yang ada di Palembang yang bergerak di bidang kuliner adalah UKM Pempek Dodo. Jumlah karyawan saat ini sebanyak 4 orang termasuk pemilik usaha pempek ini.

Pempek yang di produksi setiap harinya di UKM Pempek Dodo menggunakan bahan baku berupa ikan tenggiri, telur, sagu, dan air. Dalam sehari, UKM ini dapat memproduksi berbagai jenis pempek dengan bahan baku ikan tenggiri sebanyak 9-10 kg dan telur sebanyak 5-6 kg. Untuk pempek telur paling banyak diproduksi per harinya yaitu 4-5 kg ikan tenggiri, dengan pemakaian telur sebanyak 60-85 butir.

Pada penelitian ini, jenis pempek yang paling banyak di produksi yaitu pempek telur. Untuk membuat pempek telur membutuhkan bahan baku berupa telur. Pada proses pemisahan kuning telur, pekerja memisahkan kuning telurnya secara manual dengan menggunakan kulit telur tersebut dan membutuhkan waktu sekitar 25-40 menit.

Pada saat memisahkan telur, sering kali kuning telur tersebut pecah sehingga baskom yang berisi putih telur tercampur dengan kuning telur yang pecah tersebut.Walaupun pecahan kuning telur tersebut telah di pisahkan dari baskom putih telur, tidak menutup kemungkinan masih terdapat sisa kuning telur dalam baskom putih telur tersebut. Padahal, putih telur yang telah di pisahkan ini nanti akan di pergunakan untuk membuat tekwan dan model serta dijual. Hal lain yang terjadi yaitu pada saat pemisahan telur, kuning telur langsung jatuh ke baskom putih telur, sehingga pekerja perlu berhati-hati untuk mengambil kuning telur tersebut agar tidak pecah.

Berdasarkan permasalahan tersebut, maka peneliti ingin melakukan perancangan alat pemisah kuning telur secara manual yang bertujuan untuk mempercepat proses pemisahan kuning telur. Alat pemisah telur yang akan dirancang 
memiliki landasan telur yang dapat di sesuaikan dengan ukuran diameter baskom, sehingga dapat menggunakan baskom sendiri dan bentuknya seperti rel kereta.

Alat pemisah telur yang ada di pasaran atau yang ada di internet memiliki sistem kerja hanya dapat memisahkan telur per butir. Selain itu, alat pemisah telur yang beredar internet berbentuk lebih besar karena terdapat wadahnya sendiri untuk kuning dan putih telur, dan juga pada jalur pemisahan kuning telur kemiringannya kurang sehingga telur akan lama untuk sampai ke baskom. Pada penelitian ini, dilakukan perubahan rancangan alat berupa ide kreatif yaitu penyesuaian wadah sesuai dengan kebutuhan telur atau dapat menggunakan wadah dari UKM itu sendiri, kemiringan jalur pemisah kuning telur akan dibuat sedikit miring dari yang ada di internet serta panjang alat yang dapat disesuaikan dengan ukuran wadah penampung putih telur.

Pemilihan metode rekayasa nilai lebih cocok untuk penelitian ini dikarenakan alat yang dirancang akan lebih murah dari yang ada dipasaran dengan menggunakan material yang lebih murah dan beberapa bagian seperti penampung putih telur dapat menggunakan baskom dari UKM itu sendiri. Rancangan alat menggunakan metode rekayasa nilai diharapkan lebih murah tanpa mengurangi dari fungsi alat tersebut dan alat pemisah kuning telur ini diberi nama "AMIKUR" dimana singkatan dari alat pemisah kuning telur.

\section{METODE PENELITIAN}

Metodologi penelitian merupakan langkah penyelesaian masalah secara terencana dan sistematis. Adapun langkahlangkah yang dilakukan dalam penelitian pada gambar 1.

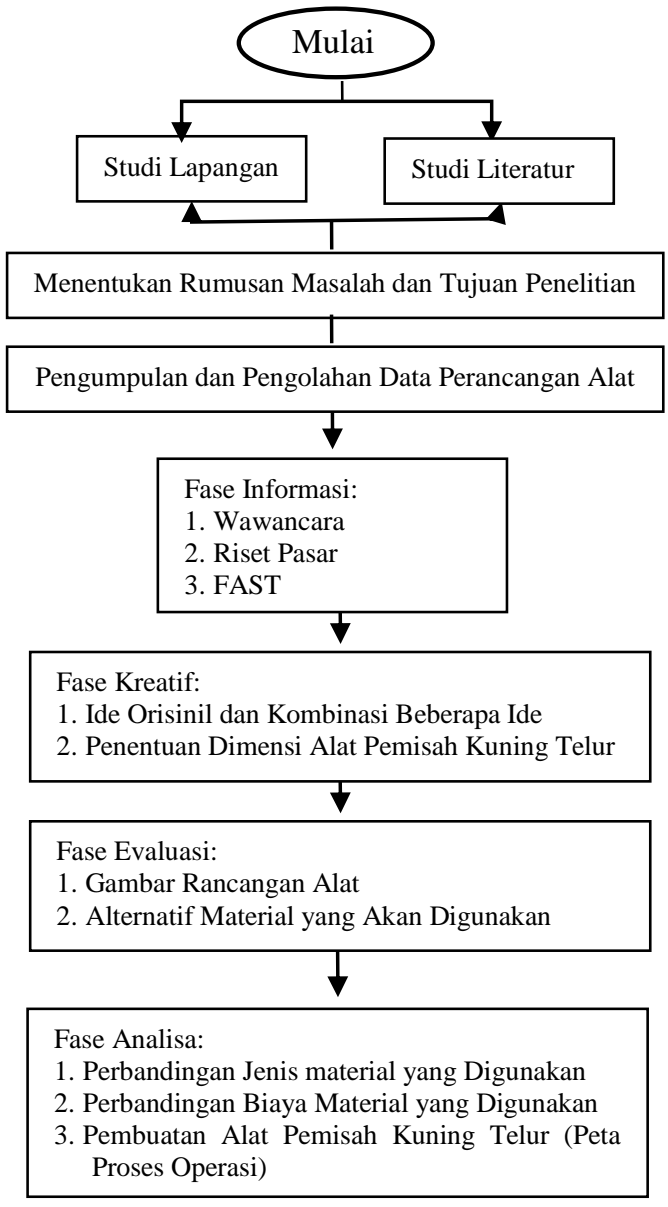

Fase Pengembangan:

1. Spesifikasi dan Cara Kerja Alat Pemisah Kuning Telur

2. Analisis Biaya (Biaya Investasi Alat Pemisah Kuning Telur, HPP, BEP, PP)

3. Perbandingan Rata-Rata Waktu Pemisahan Telur Per Butir

4. Uji Hipotesis 


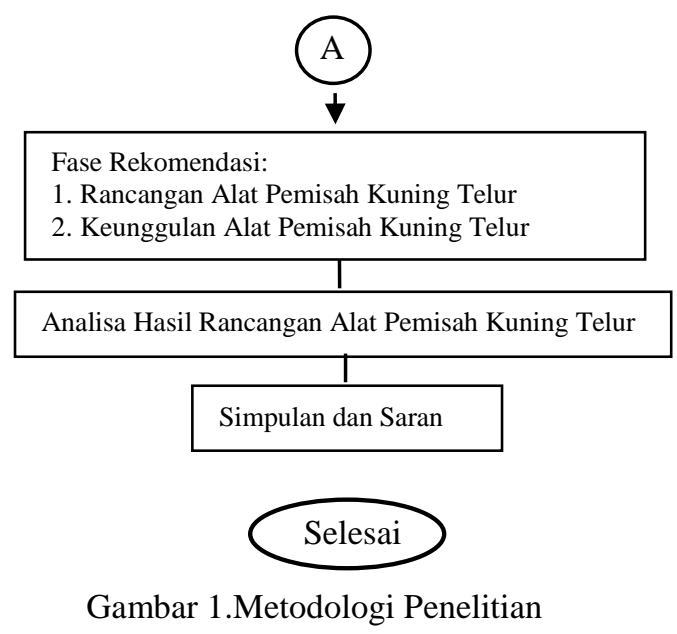

\section{HASIL DAN PEMBAHASAN}

Metode rekayasa nilai melalui beberapa tahap diantaranya :[1]

3.1 Fase Informasi

Fase informasi terdapat beberapa tahap diantaranya:

\subsubsection{Hasil Wawancara}

Spesifikasi alat yang diinginkan oleh pemilik UKM dari hasil wawancara yaitu tahan lama, aman, nyaman, mudah digunakan dan fleksibel. Berikut ini adalah rekapitulasi hasil wawancara dari alat pemisah kuning telur yang diinginkan terdapat pada tabel 1 .

Tabel 1. Hasil Wawancara

\begin{tabular}{|c|c|}
\hline Tujuan & Kriteria \\
\hline Tahan Lama & $\begin{array}{c}\text { Kuat } \\
\text { Tidak berkarat }\end{array}$ \\
\hline Aman & Tidak membuat tangan lecet \\
\hline Nyaman & Posisi tubuh ergonomi \\
\hline Mudah & Mudah disimpan \\
Digunakan & Mudah dibersihkan \\
Mudah dipindahkan
\end{tabular}

\subsubsection{Riset Pasar}

Tabel 2 merupakan hasil riset pasar alat pemisah kuning telur yang ada di pasaran.

Tabel 2. Hasil Riset Pasar Alat Pemisah Kuning Telur di Pasaran

\begin{tabular}{|c|c|c|c|}
\hline Tipe & Fungsi & Kelebihan & Kekurangan \\
\hline 1. & & $\begin{array}{l}\text { a. Digunakan secara manual } \\
\text { b. Ringan karena terbuat dari plastik } \\
\text { c. Harga terjangkau }\end{array}$ & $\begin{array}{l}\text { a. Bentuknya kecil dan seperti sendok } \\
\text { berlubang } \\
\text { b. Hanya dapat memisahkan } 1 \text { kuning } \\
\text { telur }\end{array}$ \\
\hline 2. & & $\begin{array}{l}\text { a. Bentuknya seperti tabung } \\
\text { b. Cara kerjanya yaitu dengan menyedot } \\
\text { kuning telur. } \\
\text { c. Digunakan secara manual } \\
\text { d. Ringan dan harga terjangkau } \\
\end{array}$ & $\begin{array}{l}\text { a. Bentuknya kecil dan seperti sendok } \\
\text { berlubang } \\
\text { b. Hanya dapat memisahkan } 1 \text { kuning } \\
\text { telur }\end{array}$ \\
\hline 3. & & $\begin{array}{l}\text { a. Digunakan secara manual } \\
\text { b. Dapat memisahkan kuning telur } \\
\text { secara banyak } \\
\text { c. Terdapat landasan untuk mengalirnya } \\
\text { telur } \\
\text { d. Terdapat banyak sekat-sekat pada } \\
\text { landasan }\end{array}$ & $\begin{array}{l}\text { a. Berukuran besar dan terdapat wadah } \\
\text { penampungan sehingga memakan } \\
\text { banyak tempat } \\
\text { b. Landasannya cenderung datar } \\
\text { sehingga telur lama untuk sampai ke } \\
\text { bawah } \\
\text { c. Terbuat dari stainless steel sehingga } \\
\text { harganya mahal }\end{array}$ \\
\hline
\end{tabular}




\begin{tabular}{|c|c|l|l|}
\hline Tipe & Fungsi & \multicolumn{1}{|c|}{ Kelebihan } & \multicolumn{1}{c|}{ Kekurangan } \\
\hline & & $\begin{array}{l}\text { a. Digunakan secara manual } \\
\text { b. Terdapat jalur panjang untuk } \\
\text { mengalirnya telur }\end{array}$ & $\begin{array}{l}\text { a. Alat ini hanya dapat menggunakan } \\
\text { satu jenis wadah sesuai dengan } \\
\text { panjang alat } \\
\text { c. Tidak terdapat wadah penampungan } \\
\text { putih dan kuning telur } \\
\text { b. Alat ini agak lebih berat } \\
\text { c. Terbuat dari stainless steel sehingga } \\
\text { harganya mahal }\end{array}$ \\
\hline
\end{tabular}

\subsubsection{FAST}

Berikut ini adalah diagram FAST dari alat pemisah kuning telur yang dapat dilihat pada gambar 2.

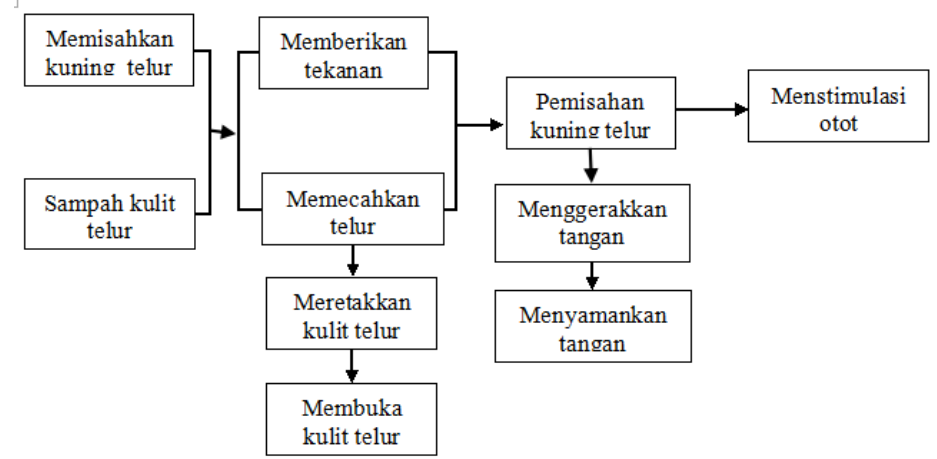

Gambar 2. Diagram FAST

\subsection{Fase Kreatif}

\subsubsection{Kombinasi Beberapa Ide}

Dari 4 tipe hasil riset pasar, akan dilakukan kombinasi untuk merancang alat pemisah kuning telur dengan pertimbangan yang dapat di lihat pada tabel 3 [2].

Tabel 3. Kombinasi Alat Pemisah Kuning Telur yang Din
\begin{tabular}{|c|l|}
\hline Tipe & \multicolumn{1}{c|}{ Keterangan } \\
\hline $1,2,3,4$ & Digunakan secara manual \\
\hline 3,4 & Dapat memisahkan banyak kuning telur \\
\hline 3,4 & Terdapat landasan untuk mengalirnya telur \\
\hline 4 & Landasannya sedikit miring \\
\hline
\end{tabular}

\subsubsection{Ide Orisinil}

Ide-ide dan pemikiran dari hasil riset pasar dituang dalam beberapa desain alat pemisah kuning telur [3]. Pada gambar 3, 4, dan 5 merupakan beberapa ide desain alat pemisah kuning telur.

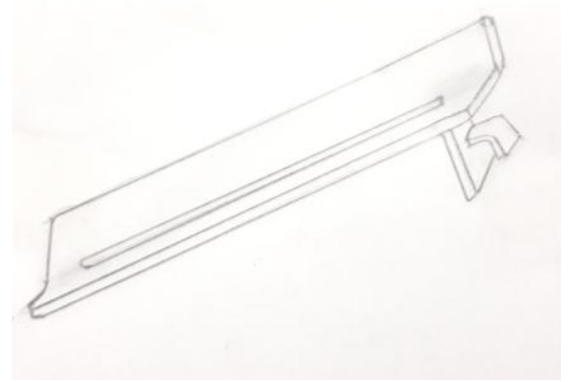

Gambar 3. Desain 1

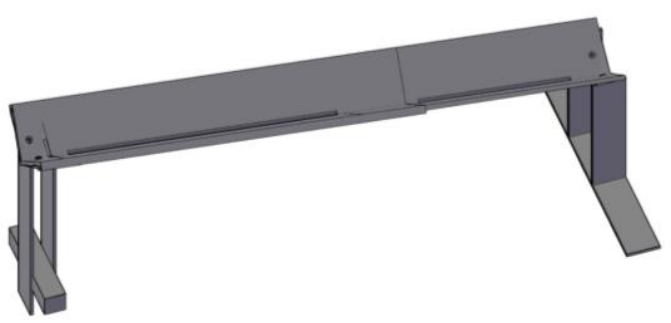

Gambar 4. Desain 2 


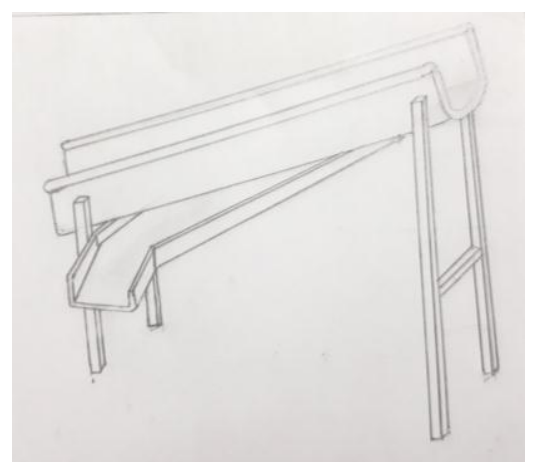

Gambar 5. Desain 3

Berdasarkan alat-alat pemisah kuning telur yang ada dipasaran, dan dilatarbelakangi oleh kombinasi beberapa ide, di pilihlah desain nomor 2 (gambar 5) dimana muncul ide orisinil dari perancangan alat pemisah kuning telur yaitu penamaan alat "AMIKUR", dan dapat disesuaikan dengan ukuran wadah.

\subsubsection{Penentuan Dimensi Ukuran Alat}

Berikut ini merupakan rekapitulasi dimensi rancangan AMIKUR yang dapat dilihat pada gambar 6 [4].

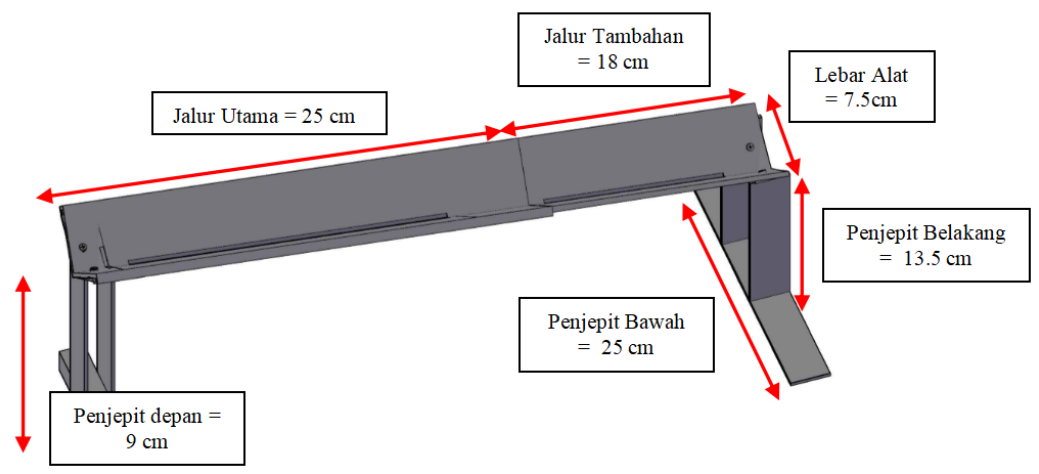

Gambar 6. Dimensi Ukuran Alat

\subsection{Fase Evaluasi}

Untuk mendesain rancangan alat pemisah kuning telur ini, peneliti menggunakan bantuan program AutoCad. Berikut ini merupakan gambar rancangan alat tampak atas dan samping pada gambar 7 dan 8 [5].

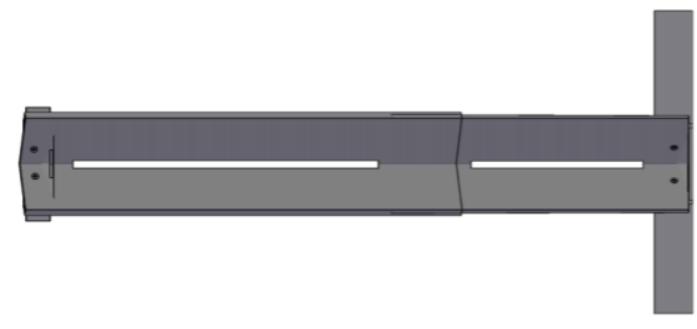

Gambar 7. Tampak Atas

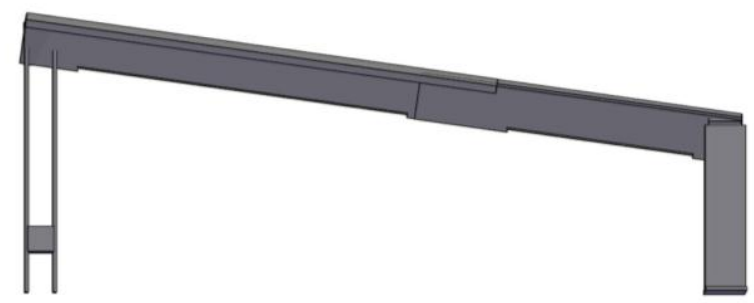

Gambar 8. Tampak Samping 


\subsection{Fase Analisa}

Dalam merancang suatu alat, pemilihan material diperlukan untuk menentukan kualitas dari produk itu sendiri. Pada tabel 4 adalah alternatif biaya yang digunakan untuk merancang alat pemisah kuning telur.

Tabel 4. Aternatif Biaya Material

\begin{tabular}{|c|c|c|}
\hline Komponen & Material & \multirow{2}{*}{ Total Biaya } \\
\cline { 1 - 2 } Landasan Telur & \multirow{2}{*}{ Stainless steel } & \multirow{2}{*}{ Rp 400.000} \\
\cline { 1 - 2 } Kaki Alat & Plat alumunium & \multirow{2}{*}{ Rp 91.000 } \\
\cline { 1 - 2 } Landasan Telur & Besi strip & \multirow{2}{*}{ Rp 221.000} \\
\cline { 1 - 2 } Kaki Alat & Stainless steel & \multirow{2}{*}{ Rp 97.000} \\
\cline { 1 - 2 } Landasan Telur & Plat Seng & Plat alumunium \\
\cline { 1 - 2 } Kaki Alat & Plat Seng & \\
\cline { 1 - 2 } Landasan Telur & &
\end{tabular}

\subsection{Fase Pengembangan}

\subsubsection{Cara Kerja AMIKUR}

Cara kerja alat pemisah kuning telur masih tradisional. Berikut ini adalah cara memisahkan kuning telur menggunakan AMIKUR:

1.Menyiapkan 2 wadah untuk kuning dan putih telur.

2.Siapkan alat pemisah kuning telur dan atur panjang alat pemisah kuning telur sesuai dengan diameter wadah yang digunakan.

3.Alat pemisah kuning telur di pasang ke wadah putih telur.

4.Pecahkan telur menggunakan garpu diatas landasan telur dan biarkan telur turun sampai ke wadah kuning telur.

\subsubsection{Analisis Biaya}

Berikut ini adalah analisis biaya yang digunakan [6]:

IV. Harga Pokok Produksi

$$
\begin{aligned}
\text { HPP per buah } & =\frac{\text { Harga pokok produksi per bulan }}{\text { Kapasistas produksi per bulan }} \\
& =\frac{R p 43,964,447,04}{17550 \text { pempek }} \\
& =\operatorname{Rp} 2.505,097
\end{aligned}
$$

V. Break Even Point dan Payback Period

$$
\begin{aligned}
& \text { BEP dalam satuan rupiah }=\frac{\text { Fixed Cost }}{1-\frac{\text { Variabel Cost }}{\text { Sales }}} \\
& =\frac{\operatorname{Rp} 3.916 .433,33}{1-\frac{\operatorname{Rp} 40.048 .013,71}{\operatorname{Rp} 52.650 .000,00}} \\
& =\operatorname{Rp} 16.362 .516,99 \\
& P P=\frac{\text { Investasi Alat }}{\text { Laba Bersih }} \\
& =\frac{\operatorname{Rp} 199.200,00}{\operatorname{Rp} 330.213,37} \\
& =0,603 \text { hari } \\
& =14,47 \mathrm{jam} \\
& \text { BEP dalam satuan unit }=\frac{\text { Fixed Cost }}{\frac{\text { Harga }}{\text { Buah }}-\frac{\text { Variabel Cost }}{\text { Buah }}} \\
& =\frac{\mathrm{Rp} 3.916 .433,33}{\operatorname{Rp} 3.0000,00-\operatorname{Rp} 2.281 .94} \\
& =5454,18 \text { buah }
\end{aligned}
$$

\subsubsection{Perbandingan Waktu Pemisahan Telur}

Pada pengukuran waktu pemisahan kuning telur sebelum impelementasi dilakukan dengan mengukur berapa lama proses pemisahan kuning telur per butir yang dilakukan dengan 40 butir telur yang terdapat pada tabel 5. 
Tabel 5. Waktu Pemisahan Kuning Telur per Butir

\begin{tabular}{|c|c|c|}
\hline \multirow{2}{*}{$\begin{array}{c}\text { Telur } \\
\text { ke- }\end{array}$} & Sebelum Implementasi & Sesudah Implementasi \\
\hline & Waktu (detik) & Waktu (detik) \\
\hline 1 & 8 & 5 \\
\hline 2 & 11 & 4 \\
\hline 3 & 10 & 6 \\
\hline 4 & 9 & 5 \\
\hline 5 & 8 & 5 \\
\hline 6 & 9 & 4 \\
\hline 7 & 7 & 4 \\
\hline 8 & 9 & 4 \\
\hline 9 & 9 & 3 \\
\hline 10 & 11 & 3 \\
\hline 11 & 13 & 5 \\
\hline 12 & 13 & 4 \\
\hline 13 & 11 & 5 \\
\hline 14 & 15 & 5 \\
\hline 15 & 12 & 5 \\
\hline 16 & 14 & 4 \\
\hline 17 & 14 & 4 \\
\hline 18 & 9 & 5 \\
\hline 19 & 10 & 6 \\
\hline 20 & 12 & 6 \\
\hline 21 & 12 & 6 \\
\hline 22 & 10 & 4 \\
\hline 23 & 8 & 4 \\
\hline 24 & 13 & 4 \\
\hline 25 & 11 & 5 \\
\hline 26 & 11 & 5 \\
\hline 27 & 8 & 5 \\
\hline 28 & 12 & 4 \\
\hline 29 & 11 & 5 \\
\hline 30 & 11 & 4 \\
\hline 31 & 9 & 5 \\
\hline 32 & 10 & 4 \\
\hline 33 & 12 & 6 \\
\hline 34 & 8 & 4 \\
\hline 35 & 16 & 3 \\
\hline 36 & 8 & 5 \\
\hline 37 & 8 & 5 \\
\hline 38 & 9 & 4 \\
\hline 39 & 10 & 5 \\
\hline 40 & 10 & 5 \\
\hline
\end{tabular}

\subsubsection{Uji Hipotesis}

Pada uji hipotesis ini digunakan dengan uji t berpasangan (paired $t$-test) [7]. Uji ini digunakan untuk menguji apakah terdapat perbandingan pemisahan kuning telur dalam sehari sebelum dan setelah menggunakan alat pemisah kuning telur. Berikut ini merupakan langkah-langkah pengujian:

VI. Menentukan hipotesis

$\mathrm{H}_{0}$ : Tidak ada perbedaan antara rata-rata waktu pemisahan kuning telur sebelum dan setelah menggunakan alat pemisah kuning telur.

$\mathrm{H}_{1}$ : Ada perbedaan antara rata-rata waktu pemisahan kuning telur sebelum dan setelah menggunakan alat pemisah kuning telur.

VII. Menentukan tingkat signifikan 
Tingkat signifikan menggunakan 0,05. Signifikan 0,05 merupakan ukuran standar yang sering digunakan dalam penelitian.

VIII. Menentukan t-hitung

Berdasarkan perhitungan dengan menggunakan bantuan software SPSS 16 diperoleh t-hitung sebesar 17,126 (dapat dilihat pada tabel 6 berikut).

Tabel 6. Paired Samples Test

\begin{tabular}{|c|c|c|c|c|c|c|c|c|c|}
\hline \multicolumn{10}{|c|}{ Paired Samples Test } \\
\hline & & \multicolumn{5}{|c|}{ Paired Differences } & \multirow[b]{3}{*}{$\mathrm{t}$} & \multirow[b]{3}{*}{ df } & \multirow{3}{*}{$\begin{array}{l}\text { Sig. (2- } \\
\text { tailed) }\end{array}$} \\
\hline & & \multirow[b]{2}{*}{ Mean } & \multirow{2}{*}{$\begin{array}{c}\text { Std. } \\
\text { Deviati } \\
\text { on }\end{array}$} & \multirow{2}{*}{$\begin{array}{l}\text { Std. } \\
\text { Error } \\
\text { Mean }\end{array}$} & \multicolumn{2}{|c|}{$\begin{array}{l}95 \% \text { Confidence } \\
\text { Interval of the } \\
\text { Difference }\end{array}$} & & & \\
\hline & & & & & Lower & Upper & & & \\
\hline Pair 1 & $\begin{array}{l}\text { Sebelum - } \\
\text { Sesudah }\end{array}$ & $\begin{array}{c}6.3250 \\
0\end{array}$ & 2.33576 & .36932 & 5.57799 & 7.07201 & 17.126 & 39 & .000 \\
\hline
\end{tabular}

\section{Menentukan t-tabel}

Tabel distribusi t dicari pada $\alpha=5 \%: 2=2,5 \%$ (uji 2 sisi) dengan $\mathrm{df}=\mathrm{n}-1=40-1=39$, maka t tabel yang diperoleh yaitu 2,023.

IX. Kriteria Pengujian

$\mathrm{H}_{0}$ diterima jika $-\mathrm{t}$ tabel $\leq \mathrm{t}$ hitung $\leq \mathrm{t}$ tabel;

$\mathrm{H}_{0}$ ditolak jika $-\mathrm{t}$ hitung $<-\mathrm{t}$ tabel atau $\mathrm{t}$ hitung $>\mathrm{t}$ tabel

Berdasarkan signifikansi:

$\mathrm{H}_{0}$ diterima jika signifikansi $>0,05$;

$\mathrm{H}_{0}$ ditolak jika signifikansi $<0,05$

$X$. Membandingkan thitung dengan $t$ tabel

Nilai t hitung $>\mathrm{t}$ tabel $(17,126>2,023)$;

Signifikansi $(0,000<0,05)$;

sehingga dapat disimpulkan bahwa $\mathrm{H}_{0}$ ditolak.

7. Gambar

\begin{tabular}{|ccc} 
& & \\
$\mathrm{H}_{0}$ & $\mathrm{H}_{1}$ & $\mathrm{H}_{0}$ \\
ditolak & diterima & ditolak \\
& & \\
\hline 2,023 & 17,126 & 2,023
\end{tabular}

Gambar 9. Kurva Penerimaan dan Penolakan H

XI.

Kesimpulan

Oleh karena $\mathrm{t}$ hitung $>\mathrm{t}$ tabel $(17,126>2,023)$ dan signifikansi $(0,000<0,05)$ maka $\mathrm{H}_{0}$ ditolak, artinya ada perbedaan antara waktu pemisahan kuning telur sebelum dan setelah menggunakan alat pemisah kuning telur.

\subsection{Fase Rekomendasi}

\subsubsection{Rancangan Desain Baru Alat}

Pada tahap ini terdapat perubahan desain alat pemisah kuning telur dengan menambahkan penjepit pada penyangga yang lebih tinggi. Berikut ini merupakan perbandingan alat pemisah kuning telur dapat dilihat pada gambar 10 adalah desain lama dan gambar 11 adalah desain baru. 


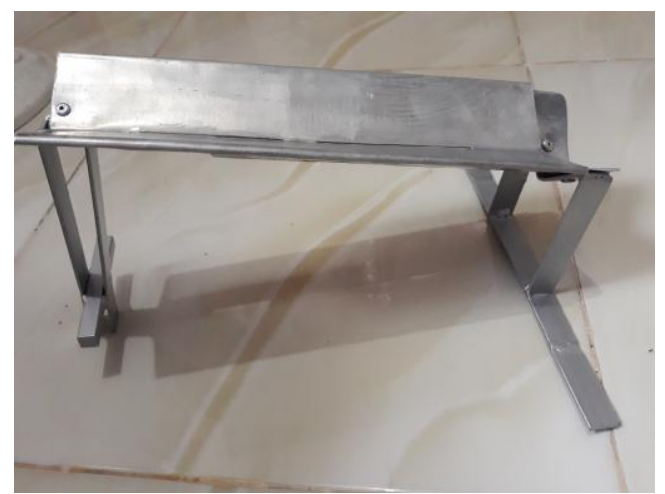

Gambar 10. AMIKUR DESAIN 1

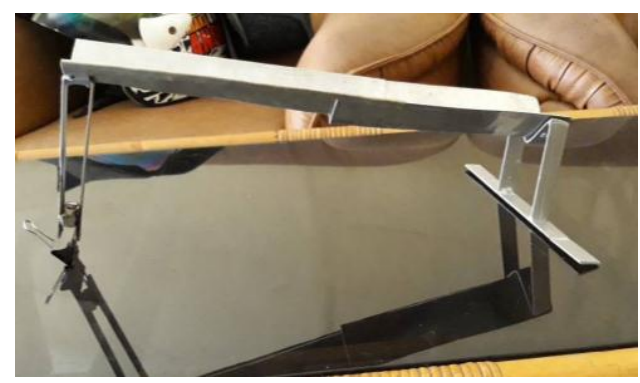

Gambar 11. AMIKUR Desain 2

\subsubsection{Kelebihan Desain Baru}

Pada desain baru alat pemisah kuning telur dengan menambahkan penjepit pada penyangga yang lebih tinggi bertujuan agar alat tersebut tidak lepas dari wadahnya. Pada tabel 7 berikut ini merupakan perincian biaya investasi perancangan alat pemisah kuning telur setelah terdapat penambahan penjepit.

Tabel 7. Perincian Biaya AMIKUR

\begin{tabular}{|c|c|c|c|c|}
\hline No. & Item & $\begin{array}{c}\text { Jumlah yang } \\
\text { Digunakan }\end{array}$ & Harga Satuan & Total \\
\hline 1. & $\begin{array}{l}\text { Plat aluminium } \\
40 \times 100 \mathrm{~cm}\end{array}$ & $20 \times 50 \mathrm{~cm}$ & Rp 76.000 & Rp 38.000 \\
\hline 2. & Besi strip & 1 meter & Rp 15.000 & Rp 15.000 \\
\hline 3. & Paku rivet & 4 buah & Rp 500 & $\mathrm{Rp} 2.000$ \\
\hline 4. & Kawat las & 3 buah & $\operatorname{Rp} 2.000$ & Rp 6.000 \\
\hline 5. & Cat chrome & 0.5 kaleng & Rp 50.000 & Rp 25.000 \\
\hline 6. & $\begin{array}{l}\text { Upah perakitan } \\
\text { dan pengelasan }\end{array}$ & 1 orang & Rp 50.000 & Rp 50.000 \\
\hline 7. & Penjepit & 1 buah & Rp 2.000 & $\mathrm{Rp} 2.000$ \\
\hline \multicolumn{4}{|c|}{ Total } & Rp 138.000 \\
\hline
\end{tabular}

\section{SIMPULAN}

Berdasarkan pengolahan data dan analisis yang telah dilakukan di UKM Pempek Dodo dapat disimpulkan bahwa hasil rancangan alat pemisah kuning telur memiliki ukuran dimensi panjang jalur utama $25 \mathrm{~cm}$, panjang jalur tambahan $18 \mathrm{~cm}$, lebar jalur telur $8 \mathrm{~cm}$, lebar alat 7,5 cm, lebar lubang $0,5 \mathrm{~cm}$, tinggi penjepit belakang $13,5 \mathrm{~cm}$, tinggi penjepit depan $9 \mathrm{~cm}$, dan panjang penjepit bawah $25 \mathrm{~cm}$. Rata-rata waktu pemisahan kuning telur secara manual yaitu selama 10,925 detik sedangkan rata-rata waktu pemisahan kuning telur dengan menggunakan alat pemisah kuning telur yaitu 4,6 detik. Hal ini menunjukkan bahwa adanya percepatan waktu sebelum dan sesudah menggunakan alat pemisah kuning telur sebesar 6,325 atau sebesar 57,89\%.

\section{DAFTAR PUSTAKA}

[1] David De Marle, LS. 1995. Value Engineering, Industrial Engineering Handbook.

[2] Pulat, Mustafa. 1992. Industrial Ergonomic Case Studies. McGraw-Hill, Inc. New York. 
JRI: Jurnal Rekayasa Industri, Vol. 1 No. 1 Oktober 2019

p-ISSN / e-ISSN

[3] Ulrich K.T, Eppinger S.D. 2008. Perancangan dan Pengembangan Produk. Salemba Teknika. Jakarta. [4] Zimmerman. LW, Hart. GD. 1982. Value Engineering, A Practical Approach for Owner, Designers and Contractors, Edisi 14, Van Nostrand Reinhold Company, New York, USA.

[5] Hutabarat, J. 1995. Diktat Rekayasa Nilai (Value Engineering). Malang: Institut Teknologi Nasional.

[6] Ahmad, Kamaruddin. 2004. Dasar-Dasar Manajemen Investasi. Edisi Revisi. Rineka Cipta, Jakarta.

[7] Duwi, Priyatno. 2010. Teknik Mudah dan Cepat Melakukan Analisis Data Penelitian dengan SPSS dan Tanya Jawab Ujian Pendadaran. Gaya Media, Yogyakarta. 